\title{
Activation of A1, A2A, or A3 adenosine receptors attenuates lung ischemia-reperfusion injury
}

\author{
Leo M. Gazoni, MD, ${ }^{a}$ Dustin M. Walters, MD, ${ }^{a}$ Eric B. Unger, BS, ${ }^{a}$ Joel Linden, $\mathrm{PhD},{ }^{\mathrm{b}}$ \\ Irving L. Kron, $\mathrm{MD},{ }^{a}$ and Victor E. Laubach, $\mathrm{PhD}^{\mathrm{a}}$
}

Objective: Adenosine and the activation of specific adenosine receptors are implicated in the attenuation of inflammation and organ ischemia-reperfusion injury. We hypothesized that activation of $A_{1}, A_{2 A}$, or $A_{3}$ adenosine receptors would provide protection against lung ischemia-reperfusion injury.

\begin{abstract}
Methods: With the use of an isolated, ventilated, blood-perfused rabbit lung model, lungs underwent 18 hours of cold ischemia followed by 2 hours of reperfusion. Lungs were administered vehicle, adenosine, or selective $\mathrm{A}_{1}$, $\mathrm{A}_{2 \mathrm{~A}}$, or $\mathrm{A}_{3}$ receptor agonists (CCPA, ATL-313, or IB-MECA, respectively) alone or with their respective antagonists (DPCPX, ZM241385, or MRS1191) during reperfusion.
\end{abstract}

\begin{abstract}
Results: Compared with the vehicle-treated control group, treatment with $\mathrm{A}_{1}, \mathrm{~A}_{2 \mathrm{~A}}$, or $\mathrm{A}_{3}$ agonists significantly improved function (increased lung compliance and oxygenation and decreased pulmonary artery pressure), decreased neutrophil infiltration by myeloperoxidase activity, decreased edema, and reduced tumor necrosis factor- $\alpha$ production. Adenosine treatment was also protective, but not to the level of the agonists. When each agonist was paired with its respective antagonist, all protective effects were blocked. The $\mathrm{A}_{2 \mathrm{~A}}$ agonist reduced pulmonary artery pressure and myeloperoxidase activity and increased oxygenation to a greater degree than the $A_{1}$ or $A_{3}$ agonists.
\end{abstract}

Conclusion: Selective activation of $\mathrm{A}_{1}, \mathrm{~A}_{2 \mathrm{~A}}$, or $\mathrm{A}_{3}$ adenosine receptors provides significant protection against lung ischemia-reperfusion injury. The decreased elaboration of the potent proinflammatory cytokine tumor necrosis factor- $\alpha$ and decreased neutrophil sequestration likely contribute to the overall improvement in pulmonary function. These results provide evidence for the therapeutic potential of specific adenosine receptor agonists in lung transplant recipients. (J Thorac Cardiovasc Surg 2010;140:440-6)

Primary graft dysfunction (PGD), the most severe form of ischemia-reperfusion (IR) injury, continues to be a major cause of morbidity and mortality after lung transplantation. The most recent report from the International Society for Heart and Lung Transplantation reported that PGD was the leading cause of death $(28.8 \%$ of patient deaths) within the first 30 days after transplant. ${ }^{1}$ Although the overall incidence of lung IR injury has remained fairly constant $(\sim<25 \%)$, the 30-day mortality after transplant has improved over the past 2 decades primarily because of reductions in PGD. ${ }^{2}$ The clinical significance of lung IR injury is further magnified by its association with the development of bronchiolitis obliterans. ${ }^{3} \mathrm{Im}$ proving outcomes after lung transplantation and extending the

From the Departments of Surgery ${ }^{\mathrm{a}}$ and Medicine, ${ }^{\mathrm{b}}$ University of Virginia Health System, Charlottesville, Va.

This study was supported by National Institutes of Health R01HL092953 (to V.E.L. and I.L.K.), National Institutes of Health T32HL007849 (to I.L.K.), and the Roche Organ Transplant Research Foundation (to V.E.L.).

Disclosures: Drs Linden and Kron were shareholders in Adenosine Therapeutics, LLC, the corporation that provided ATL-313, at the time of the study.

Received for publication Aug 20, 2009; revisions received Dec 8, 2009; accepted for publication March 1, 2010; available ahead of print April 16, 2010.

Address for reprints: Victor E. Laubach, PhD, Department of Surgery, University of Virginia Health System, PO Box 801359, Charlottesville, VA 22908 (E-mail: laubach@virginia.edu).

0022-5223/\$36.00

Copyright (c) 2010 by The American Association for Thoracic Surgery doi:10.1016/j.jtcvs.2010.03.002 donor pool and recipient criteria are predicated on the ability to minimize the deleterious inflammatory responses that occur with lung IR injury.

Adenosine is an endogenous mediator that typically serves as a cytoprotective modulator in response to stress. Many studies have demonstrated the protective effects of adenosine in the setting of organ IR injury. Adenosine signals through 4 subtypes of the $G$ protein-coupled receptor, $A_{1}, A_{2 A}, A_{2 B}$, and $\mathrm{A}_{3}$, all of which are expressed in the lung. Protective effects of adenosine receptor signaling classically occur through second messenger pathways, such as cAMP production or the phospholipase $\mathrm{C}$ pathway. Our laboratory has extensively studied selective $A_{2 A}$ receptor activation and shown it to provide significant protection against lung IR injury. ${ }^{4-6}$ However, the effects of specific activation of $\mathrm{A}_{1}, \mathrm{~A}_{2 \mathrm{~B}}$, and $\mathrm{A}_{3}$ adenosine receptors in lung IR injury remain poorly understood. Previous studies have provided evidence that $A_{1}$ and $A_{3}$ receptors may primarily be involved in anti-inflammatory actions, ${ }^{7,8}$ whereas the $\mathrm{A}_{2 \mathrm{~B}}$ receptor may have more proinflammatory actions ${ }^{9}$ in the lung. The objective of this study is to further define the protective effects of adenosine receptor subtypes, using specific agonists and antagonists, on lung IR injury. We hypothesize that specific activation of $A_{1}, A_{2 A}$, or $A_{3}$ receptors provides significant protection from lung injury and dysfunction after IR. The use of specific adenosine receptor agonists and antagonists in an isolated, 

Abbreviations and Acronyms
$\mathrm{BAL}=$ bronchoalveolar lavage
IR = ischemia-reperfusion
MPO = myeloperoxidase
PA = pulmonary artery
PGD = primary graft dysfunction
$\mathrm{TNF}-\alpha=$ tumor necrosis factor-alpha

blood-perfused rabbit model of lung IR will be used to test this hypothesis.

\section{MATERIALS AND METHODS Animal Care}

New Zealand white rabbits (Burleson Enterprises, Inc, Unionville, Va) of both genders (3.0-3.5 kg) were used in this study and received humane care in accordance with the "Guide for Care and Use of Laboratory Animals," published by the National Institutes of Health (publication no. 85-23, revised 1995). The study protocol was reviewed and approved by the animal care and use committee at the University of Virginia.

\section{Experimental Protocol}

Eight experimental groups of lungs ( $n=6 /$ group) were compared using an isolated, whole-blood perfused, ventilated rabbit lung model of IR (Kent Scientific, Model TIS3862, Litchfield, CT) as previously described. ${ }^{4}$ All lungs were reperfused for 120 minutes after 18 hours of cold ischemic storage, time periods that we previously demonstrated to result in reproducible injury versus sham lungs. ${ }^{4}$ Lungs received vehicle (dimethylsulfoxide), adenosine, or a specific adenosine receptor agonist (with or without its respective antagonist), as summarized in Table 1. Each agonist used in this study is potent and specific for its target: IB-MECA is reported to be approximately 50 -fold selective for $\mathrm{A}_{3}$ versus $\mathrm{A}_{1}$ or $\mathrm{A}_{2 \mathrm{~A}} ;{ }^{10} \mathrm{ATL}-313$ is selective for $A_{2 A}$ versus $A_{1}$ (81-fold) and $A_{3}$ (350-fold); ${ }^{11}$ and CCPA is reported to be approximately 53 -fold selective for $A_{1}$ versus $A_{2 A}$ or $A_{3}{ }^{12}$ Each receptor agonist or antagonist was added to the whole-blood perfusate at the beginning of reperfusion (see Table 1 for specific doses). The doses used were based on well-established doses used in previous studies and do not result in significant cardiovascular effects. ${ }^{4,13,14}$ Adenosine was administered by constant infusion $(0.75 \mathrm{mg} / \mathrm{kg} / \mathrm{min})$ during reperfusion because of its short half-life of several seconds in whole blood.

\section{Harvest Procedure}

Animals were randomly assigned to each experimental group. Each animal was anesthetized with intramuscular ketamine $(50 \mathrm{mg} / \mathrm{kg})$ and xylazine $(5 \mathrm{mg} / \mathrm{kg})$. Tracheal intubation was performed via a tracheostomy, and mechanical ventilation (Kent Scientific, Model RSP1002) was instituted with room air at a respiratory rate of 30 breaths/min. Median sternotomy and thymectomy were performed. The aorta and pulmonary artery (PA) were encircled, and $1000 \mathrm{U} / \mathrm{kg}$ heparin was administered intravenously. Prostaglandin E1 $(30 \mathrm{mg})$ was then administered via the PA, and the vena cavae were ligated to initiate ischemia 5 minutes after heparin administration. The PA was then cannulated through a ventriculotomy made within a pursestring placed in the right ventricular outflow tract. After the left ventricle was vented through a left ventriculotomy and the aorta was ligated, $100 \mathrm{~mL} / \mathrm{kg}$ of buffered Perfadex (Vitrolife, Kungsbacka, Sweden) preservation solution was infused into the PA at a pressure of $30 \mathrm{~cm} \mathrm{H}_{2} \mathrm{O}$ at $4{ }^{\circ} \mathrm{C}$. Topical cooling was achieved with cold saline solution slush. The left atrium was cannulated through the left ventriculotomy with an outflow catheter. The lung-heart block was excised. The lungs were stored inflated at $4^{\circ} \mathrm{C}$ for 18 hours.

\section{Reperfusion Procedure}

A force transducer suspended the heart-lung block, and ventilation was initiated with a $95 \%$ oxygen and $5 \%$ carbon dioxide gas mixture (Kent Scientific, Model RSP1002). All groups underwent 120 minutes of whole-blood perfusion at $37^{\circ} \mathrm{C}$. Atelectasis was grossly eliminated by administering 1 breath of approximately $30 \mathrm{~cm} \mathrm{H}_{2} \mathrm{O}$ positive end-expiratory pressure once per minute during the first 5 minutes of the stabilization period. Lungs were ventilated at a constant tidal volume of $10 \mathrm{~mL} / \mathrm{kg}$ with 3 $\mathrm{cm} \mathrm{H}_{2} \mathrm{O}$ of positive end-expiratory pressure at a rate of 30 breaths $/ \mathrm{min}$. The PA and outflow catheters connected the lung-heart block to a venous blood reperfusion circuit. New Zealand white rabbits served as fresh venous blood donors. Blood was circulated through a pediatric oxygenator set to deoxygenate the blood and add carbon dioxide to simulate venous blood $\left(\mathrm{Po}_{2}=60 \mathrm{~mm} \mathrm{Hg} / \mathrm{PCO}_{2}=60 \mathrm{~mm} \mathrm{Hg}\right)$. The lungs were subsequently perfused via the PA cannula at $60 \mathrm{~mL} / \mathrm{min}$ with "venous" blood at $37^{\circ} \mathrm{C}$.

\section{Lung Physiology}

A dynamic data acquisition program (DASYLab; DASYTEC, USA, Bedford, $\mathrm{NH}$ ) recorded PA pressure and pulmonary compliance. Pulmonary venous blood samples were collected for blood gas analysis (Bayer $348 \mathrm{pH} /$ Blood Gas Analyzer; Bayer Corp, E Walpole, Mass) at 15, 30, 60, 90, and 120 minutes after initiation of reperfusion.

\section{Lung Wet/Dry Weight}

The lung wet/dry weight ratio was used to assess pulmonary edema. After the 120-minute reperfusion period, fresh samples of lung tissue were collected from the right lower lobe of the left lung. Fresh lung samples were blotted to remove excess blood; they were then weighed and desiccated under vacuum at $55^{\circ} \mathrm{C}$ until a stable dry weight was achieved.

\section{Myeloperoxidase Activity}

Neutrophil sequestration was assessed by measuring myeloperoxidase (MPO) activity in left lung tissue, as previously described by our laboratory. ${ }^{5}$

\section{Bronchoalveolar Lavage}

Bronchoalveolar lavage (BAL) was performed on all lungs at the end of the reperfusion period. The right upper and middle lobes were isolated and lavaged with $10 \mathrm{~mL}$ normal saline. The BAL fluid was then centrifuged at $1500 \mathrm{~g}$ for 5 minutes at $4^{\circ} \mathrm{C}$. The supernatant was stored at $-80^{\circ} \mathrm{C}$ until analysis.

\section{Measurement of Tumor Necrosis Factor- $\alpha$}

Protein levels of tumor necrosis factor (TNF)- $\alpha$ in BAL fluid were measured using a TNF- $\alpha$ enzyme-linked immunosorbent assay kit (BD Biosciences, San Diego, Calif) as instructed by the manufacturer. Samples were assessed in triplicate.

\section{Statistics}

Values are expressed as the mean \pm standard error of the mean. Analysis of variance was used to determine whether significant differences existed among the groups. Tukey's honestly significant difference multiplecomparison test was used to determine which groups were significantly different when the analysis of variance results were significant. Repeatedmeasures analysis of variance was performed and ultimately allowed us to conclude that PA pressure, lung compliance, and oxygenation changed over time and depended on the group.

\section{RESULTS}

\section{Lung Physiology}

Selective activation of $A_{1}$ and $A_{2 A}$ receptors during reperfusion resulted in significant decreases in PA pressure versus control at the end of the 120-minute reperfusion period 
TABLE 1. Adenosine receptor agonists and antagonists used

\begin{tabular}{|c|c|c|}
\hline $\begin{array}{l}\text { Adenosine } \\
\text { receptor }\end{array}$ & $\begin{array}{c}\text { Agonist } \\
\text { (dose, source) }\end{array}$ & $\begin{array}{c}\text { Antagonist } \\
\text { (dose, source) }\end{array}$ \\
\hline $\mathrm{A}_{1}$ & $\begin{array}{l}\text { CCPA } \\
(10 \mathrm{nM} ; \text { Sigma, St Louis, Mo) }\end{array}$ & $\begin{array}{l}\text { DPCPX } \\
(100 \mathrm{nM} ; \text { Sigma })\end{array}$ \\
\hline $\mathrm{A}_{2 \mathrm{~A}}$ & $\begin{array}{l}\text { ATL-313 } \\
\text { (100 nM; Dr J. Linden) }\end{array}$ & $\begin{array}{l}\text { ZM241385 (100 nM; Tocris } \\
\text { Bioscience, Ellisville, Mo) }\end{array}$ \\
\hline $\mathrm{A}_{3}$ & $\begin{array}{l}\text { IB-MECA } \\
(60 \mathrm{nM} ; \text { Sigma })\end{array}$ & $\begin{array}{l}\text { MRS1191 } \\
\text { (10 nM; Sigma) }\end{array}$ \\
\hline All & $\begin{array}{l}\text { Adenosine } \\
(0.75 \mathrm{mg} / \mathrm{kg} / \mathrm{min} ; \text { Sigma })\end{array}$ & NA \\
\hline
\end{tabular}

CCPA, 2-chloro-N(6)-cyclopentyladenosine; $A T L-313,4$-\{3-[6-amino-9-(5-cyclopropylcarbamoyl-3,4-dihydroxy-tetrahydro-furan-2-yl)- $9 H$-purin-2-yl]-prop-2-ynyl \}-pip eridine-1-carboxylic acid methyl ester; IB-MECA, 2-chloro- $\mathrm{N}^{6}$-(3-iodobenzyl) adenosine-5'-N-methyluronamide; $D P C P X, 8$-cyclopentyl-1,3-dipropylxanthine; ZM 241385, 4-(2-[7-Amino-2-[2-furyl][1,2,4]triazolo[2,3-a][1,3,5]triazin-5-yl-amino]ethyl); MRS 1191, 3-ethyl-5-benzyl-2-methyl-6-phenyl-4-phenylethynyl-1, 4( \pm -dihydropyridine-3,5-dicarboxylate

(Figure $1, A)$. In addition, significant decreases in PA pressure were observed in the $\mathrm{A}_{2 \mathrm{~A}}$ agonist-treated group relative to treatment with $\mathrm{A}_{1}$ or $\mathrm{A}_{3}$ agonists (Figure $1, A$ ). The $\mathrm{A}_{3}$ receptor agonist reduced $\mathrm{PA}$ pressure somewhat, but not significantly. The $A_{1}, A_{2 A}$, and $A_{3}$ receptor agonists resulted in significant increases in lung compliance (Figure 1, B) and oxygenation (Figure 1,C) compared with control at 120 minutes of reperfusion. Oxygenation was significantly higher in the $A_{2 \mathrm{~A}}$ agonist-treated group versus treatment with $A_{1}$ or $A_{3}$ agonists (Figure $1, C$ ). The improvements in the aforementioned physiologic measurements by each agonist were all blocked by the concomitant administration of antagonist (Table 2). Although adenosine administration resulted in significant improvement of PA pressure, lung compliance, and oxygenation, these improvements were generally not as great as for the receptor agonists.

\section{Production of Tumor Necrosis Factor- $\alpha$}

Treatment with $\mathrm{A}_{1}, \mathrm{~A}_{2 \mathrm{~A}}$, and $\mathrm{A}_{3}$ receptor agonists, and adenosine resulted in significantly less production of the proinflammatory cytokine TNF- $\alpha$ versus control (Figure 2, A). The administration of each receptor agonist with its respective antagonist blocked the decrease in TNF- $\alpha$ (Table 3). No significant difference in TNF- $\alpha$ production occurred among the agonist-treated groups. Each receptor agonist resulted in significantly lower TNF- $\alpha$ production compared with adenosine alone.

\section{Myeloperoxidase Activity}

MPO activity was used as an indicator of neutrophil sequestration into the lung. Treatment with $\mathrm{A}_{1}, \mathrm{~A}_{2 \mathrm{~A}}$, and $\mathrm{A}_{3}$ receptor agonists, and adenosine resulted in significant decreases in MPO activity versus control (Figure 2, B). The administration of each receptor agonist with its respective antagonist blocked the decrease in MPO activity (Table 3). Selective $A_{2 A}$ receptor activation resulted in the
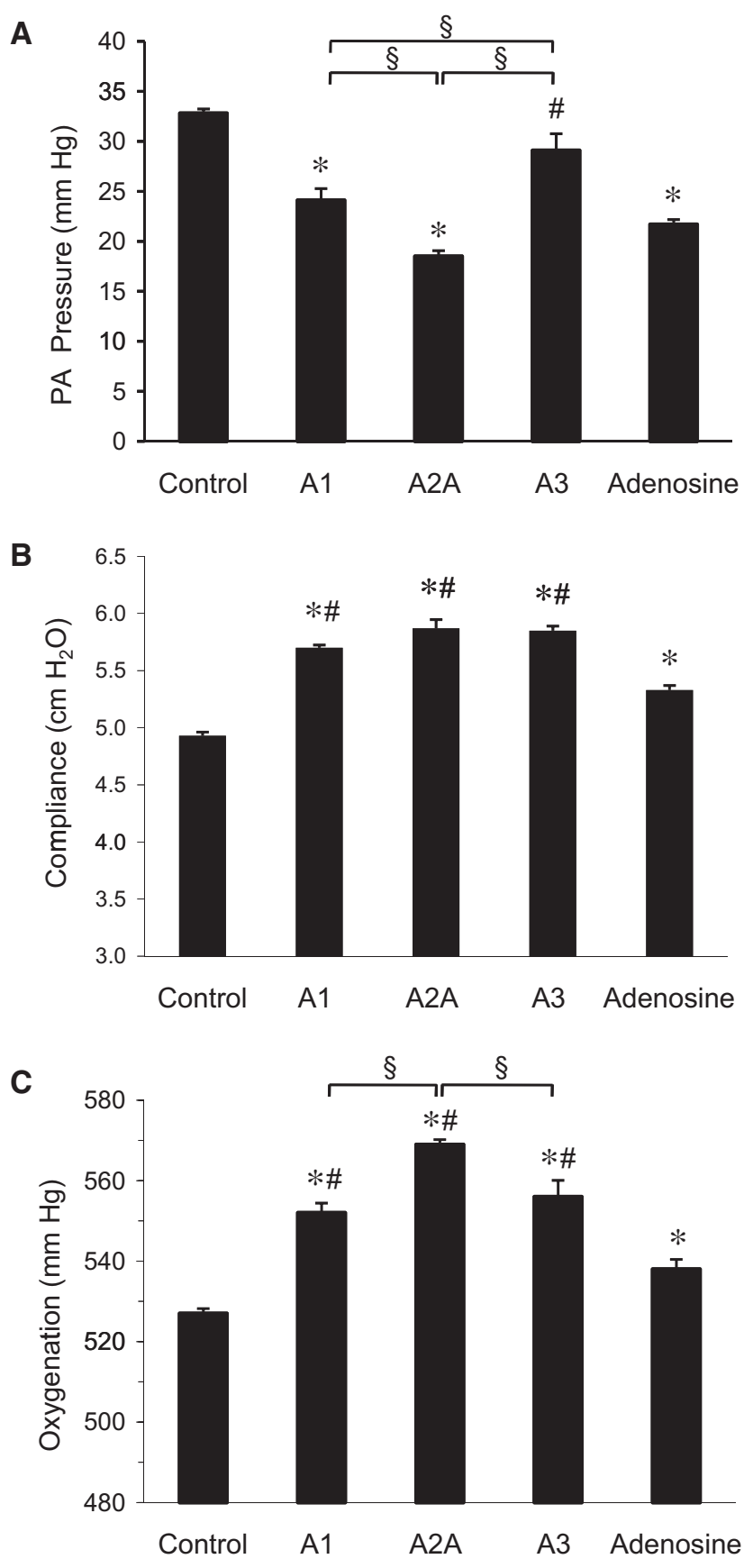

FIGURE 1. Lung function. Comparison of PA pressure (A), pulmonary compliance (B), and oxygenation (C) among groups at the end of the 120 -minute reperfusion period. $* P<.0002$ versus control. $\# P<.02$ versus adenosine. $\S P<.02$. $P A$, Pulmonary artery.

greatest decrease in MPO activity (44\% reduction vs control). Each receptor agonist resulted in significantly less MPO activity compared with adenosine alone.

\section{Wet/Dry Weight Ratio}

Lung wet/dry weight ratio was measured to assess pulmonary edema. Treatment with $\mathrm{A}_{1}, \mathrm{~A}_{2 \mathrm{~A}}$, and $\mathrm{A}_{3}$ receptor 
TABLE 2. Pulmonary function at the end of the 120-minute reperfusion period

\begin{tabular}{|c|c|c|c|}
\hline Group & $\begin{array}{c}\text { PA pressure } \\
(\mathbf{m m ~ H g})\end{array}$ & $\begin{array}{c}\text { Compliance } \\
\left(\mathrm{cm} \mathrm{H}_{2} \mathrm{O}\right)\end{array}$ & $\begin{array}{c}\text { Oxygenation } \\
\text { (mm Hg) }\end{array}$ \\
\hline Control & $32.83 \pm 0.48$ & $4.93 \pm 0.03$ & $527.7 \pm 1.1$ \\
\hline $\mathrm{A}_{1}$ agonist & $24.17 \pm 1.19^{*}, \S$ & $5.70 \pm 0.03^{*}, \dagger$ & $551.7 \pm 2.2^{*}, \dagger$ \\
\hline $\mathrm{A}_{1}$ agonist + antagonist & $31.67 \pm 0.56 \dagger$ & $5.07 \pm 0.03 \dagger$ & $527.0 \pm 2.1$ \\
\hline $\mathrm{A}_{2 \mathrm{~A}}$ agonist & $18.50 \pm 0.62^{*}, \ddagger, \S$ & $5.87 \pm 0.08^{*}, \dagger$ & $569.2 \pm 1.1^{*}, \dagger, \ddagger, \S$ \\
\hline $\mathrm{A}_{2 \mathrm{~A}}$ agonist + antagonist & $31.33 \pm 0.84 \dagger$ & $5.12 \pm 0.48 \dagger$ & $525.3 \pm 2.9 \dagger$ \\
\hline $\mathrm{A}_{3}$ agonist & $29.17 \pm 1.66 \dagger, \ddagger$ & $5.85 \pm 0.04^{*}, \dagger$ & $556.2 \pm 4.0^{*}, \dagger$ \\
\hline $\mathrm{A}_{3}$ agonist + antagonist & $32.00 \pm 1.59 \dagger$ & $5.07 \pm 0.06 \dagger$ & $530.0 \pm 3.5$ \\
\hline Adenosine & $21.67 \pm 0.49^{*}$ & $5.33 \pm 0.04^{*}$ & $538.3 \pm 2.5^{*}$ \\
\hline
\end{tabular}

$P A$, Pulmonary artery. ${ }^{*} P<.0002$ vs control. $\uparrow P<.02$ vs adenosine. $\ddagger P<.01$ vs $\mathrm{A}_{1}$ agonist. $\S P<.02$ vs $\mathrm{A}_{3}$ agonist.

agonists, and adenosine resulted in significantly less wet/dry weight versus control (Figure 2, C). The administration of each receptor agonist with its respective antagonist blocked the decrease in wet/dry weight (Table 3). No significant difference in wet/dry weight occurred between the agonist- and adenosine-treated groups.

\section{DISCUSSION}

Pharmacologic modulation of specific adenosine receptors may be a useful therapeutic method for attenuating lung IR injury, thus improving patient outcomes after lung transplantation. Although the anti-inflammatory effects of adenosine are well described, the ability to translate adenosine-related therapeutics into clinical practice requires better understanding of the relationship between adenosine receptor subtypes and end-organ effect. The protective as well as deleterious profile of adenosine receptors with respect to lung IR injury is poorly understood. A modest number of studies have begun to evaluate the role of single adenosine receptors in lung IR injury. ${ }^{4,7,15}$ However, it is difficult to compare and contrast the role of different adenosine receptor subtypes between these various studies and models. The present study better characterizes and compares the effects of specific activation of $A_{1}, A_{2 A}$, and $A_{3}$ receptors in an accepted, reproducible model of lung IR injury.

Of the adenosine receptor subtypes, $\mathrm{A}_{2 \mathrm{~A}}$ receptor activation has most consistently demonstrated potent antiinflammatory properties and has repeatedly attenuated lung IR injury in various studies. For example, $\mathrm{A}_{2 \mathrm{~A}}$ agonists have been associated with inhibition of inflammatory cytokine release, reduction of IR-induced apoptotic injury, and diminution of free radical production. ${ }^{416}$ In addition, neutrophil-induced IR injury is directly abrogated by selective $\mathrm{A}_{2 \mathrm{~A}}$ receptor activation. ${ }^{17}$ The attenuation of lung dysfunction and injury after IR by $\mathrm{A}_{2 \mathrm{~A}}$ agonists observed in prior studies was confirmed in the present study. Compared with $\mathrm{A}_{1}$ and $\mathrm{A}_{3}$ receptor agonists, the $\mathrm{A}_{2 \mathrm{~A}}$ agonist provided greater protection (eg, lower PA pressure, improved oxygenation, and reduced MPO activity), possibly because $\mathrm{A}_{2 \mathrm{~A}}$ receptors are predominantly expressed on inflammatory cells, including neutrophils, mast cells, macrophages, mono- cytes, and $\mathrm{T}$ cells. It has been shown that $\mathrm{A}_{2 \mathrm{~A}}$ receptor activation prevents leukocyte adhesion to endothelial cells and inhibits the release of toxic oxygen products. ${ }^{18}$

Studies on the role of $A_{1}$ receptor activation in lung IR injury have been somewhat confusing. Although the $A_{1}$ receptor has been shown to play a protective role after IR in the heart, ${ }^{19}$ intestine ${ }^{20}$ liver, ${ }^{8}$ and kidney, ${ }^{21}$ an early study by Neely and Keith ${ }^{15}$ concluded that $\mathrm{A}_{1}$ receptor antagonists block lung IR injury. Paradoxically, $A_{1}$ receptor activation with CCPA was shown to exert a cytoprotective role against IR injury in skeletal muscle, an effect that was blocked by the $\mathrm{A}_{1}$ receptor antagonist DPCPX. ${ }^{22}$ In the current study, $\mathrm{A}_{1}$ receptor activation by CCPA improved lung function in association with decreased neutrophil infiltration (MPO activity), inflammatory cytokine production (TNF- $\alpha$ ), and edema (wet/dry weight). Notably, these protective effects were blocked by DPCPX. One possible explanation for the differing conclusions between our study and Neely and Keith's study could involve differences in the model. Neely and Keith used an in vivo model in which the left lower lobe in cats with intact chests was rendered ischemic for 2 hours and reperfused for 2 hours. A more likely explanation could involve a difference in DPCPX administration: We used DPCPX at a concentration of $100 \mathrm{nM}$ in the whole-blood reperfusate, whereas Neely and Keith used a bolus dose of $6 \mathrm{mg} / \mathrm{kg}$ DPCPX to the cat either 30 minutes before ischemia or 1 hour after reperfusion. We estimate that this dose resulted in a blood concentration of DPCPX at least 700fold greater than our dose of $100 \mathrm{nM}$, a dose that could lead to unwanted side effects, such as the nonspecific antagonism of other (anti-inflammatory) adenosine receptors. Although $100 \mathrm{nM}$ DPCPX was efficient in blocking the protective effects of the A1 agonist CCPA in our study, we did not test the effect of DPCPX alone.

Proinflammatory properties of the $\mathrm{A}_{3}$ receptor have been demonstrated by mast-cell degranulation resulting from administration of IB-MECA. ${ }^{23}$ On the other hand, $\mathrm{A}_{3}$ receptor activation reduces degranulation and free radical formation from eosinophils. ${ }^{24}$ More anti-inflammatory effects, however, have been associated with $\mathrm{A}_{3}$ receptor activation. For example, activation of the $A_{3}$ receptor was shown to suppress 

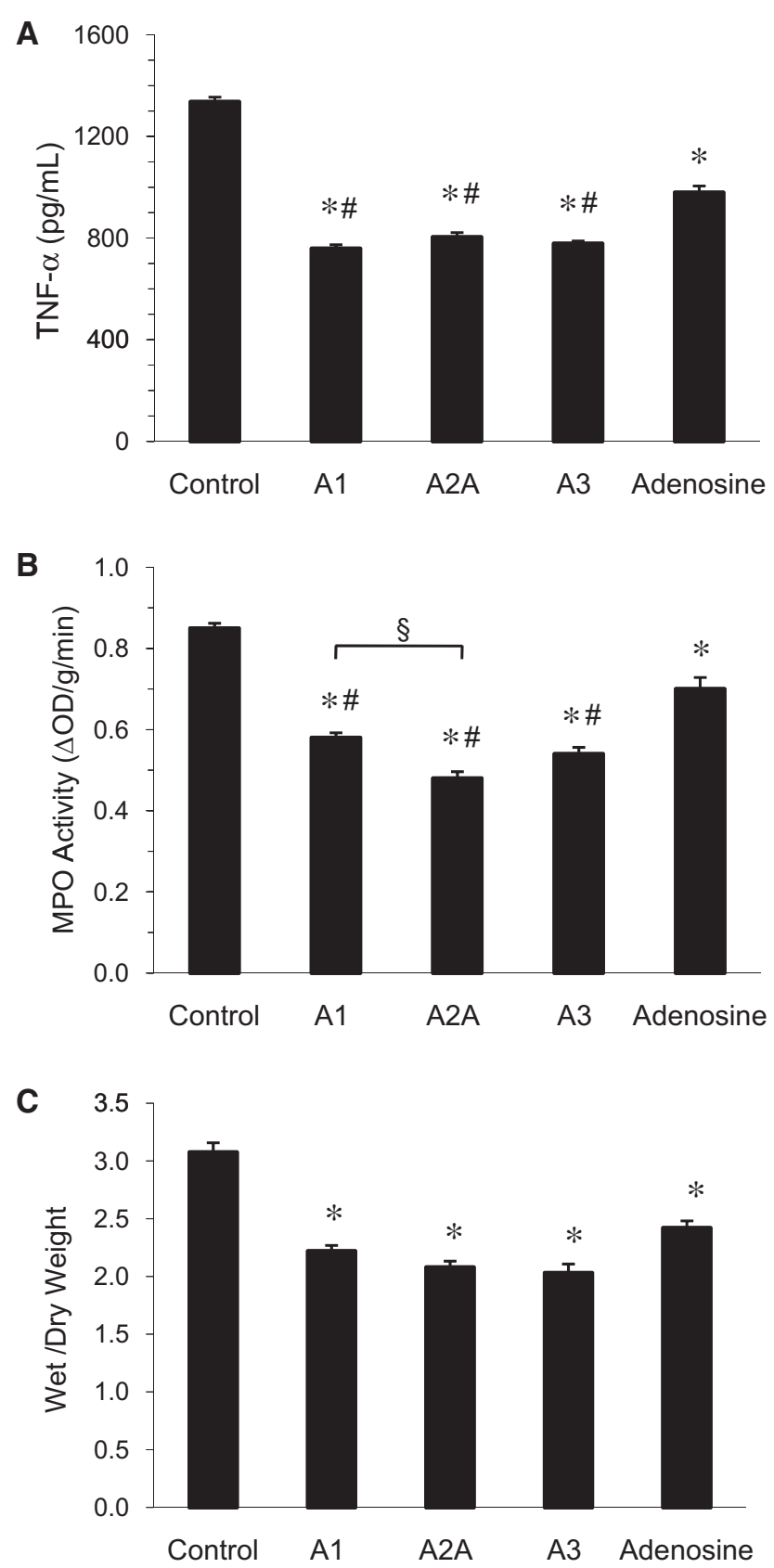

FIGURE 2. Lung injury. Comparison of TNF- $\alpha$ levels in BAL fluid (A), MPO activity (B), and lung wet/dry weight ratio (C) among groups at the end of the 120 -minute reperfusion period. $* P<.0002$ versus control. $\# P<.01$ versus adenosine. $\S P<.01 . T N F-\alpha$, Tumor necrosis factor; $M P O$, myeloperoxidase.

superoxide production and chemotaxis in mouse neutrophils. ${ }^{25}$ Moreover, various studies have demonstrated that $\mathrm{A}_{3}$ agonists reduce IR-associated myocardial injury. ${ }^{26,27}$ In a study of feline lung IR injury, Rivo and colleagues ${ }^{7}$ showed that $\mathrm{A}_{3}$ receptor activation with IB-MECA reduced alveolar injury, wet/dry weight, MPO activity, and apoptosis. In support of these data, the current study found that IB-MECA pro- vided significant protection against lung dysfunction and injury after IR. However, $A_{3}$ receptor activation differed from $A_{1}$ and $A_{2 A}$ receptor activation in that it did not significantly decrease PA pressure versus control.

The administration of adenosine during reperfusion reduced PA pressure and increased lung compliance and oxygenation. The $\mathrm{A}_{1}, \mathrm{~A}_{2 \mathrm{~A}}$, and $\mathrm{A}_{3}$ receptor agonists all improved oxygenation and lung compliance to a greater extent than adenosine alone. Although adenosine infusion did decrease TNF- $\alpha$ production and MPO activity versus control, this was not as great a decrease as observed with the $\mathrm{A}_{1}, \mathrm{~A}_{2 \mathrm{~A}}$, and $\mathrm{A}_{3}$ agonists. This may account for the poorer lung function with adenosine treatment compared with the agonists. Adenosine has also been shown to enhance the release of histamine from mast cells and potentiate the bronchoconstrictor response in patients with chronic obstructive pulmonary disorder and asthma. ${ }^{24}$ Interactions and crosstalk between the adenosine receptors themselves also remain largely unknown and might account for differences in endorgan effect between adenosine administration and selective adenosine receptor activation. Finally, adenosine could also be activating the $\mathrm{A}_{2 \mathrm{~B}}$ receptor, a pathway that may be proinflammatory in this setting.

Although small but significant differences in oxygenation were observed as summarized, all of the $\mathrm{Po}_{2}$ levels were greater than $500 \mathrm{~mm} \mathrm{Hg}$. This high degree of oxygenation would likely not make a large clinical difference. However, we reported $\mathrm{Po}_{2}$ levels in this study to complete the data and illustrate that the observed significant differences in oxygenation correlated well with other differences in physiologic parameters, such as PA pressure and pulmonary compliance.

As stated in the "Materials and Methods" section, the doses of agonist used in our study were based on wellestablished doses used in previous studies and do not result in significant cardiovascular effects. Thus, it is unlikely that the protective effects of the agonists were primarily physiologic. The reductions in PA pressure observed with the use of the agonists are likely secondary to the anti-inflammatory affects of the agonists. The mechanism responsible for these anti-inflammatory effects is not completely understood. Adenosine receptors couple, via $G$ proteins, to an intricate network of second messenger signaling pathways, such as modulation of cAMP production or phospholipase C. However, the effects of $\mathrm{G}$ protein coupling can differ substantially between receptor subtypes. In addition, they are known to couple to mitogen-activated protein kinases, indicating a possible role in cell growth, differentiation, survival, and death. Current studies in our laboratory are evaluating mechanisms of action and what cell types are most responsible for the protective effects of adenosine receptors in the setting of lung IR injury.

The role of the $A_{2 B}$ receptor in lung IR injury remains largely unknown because no selective, potent $A_{2 B}$ agonists yet exist. Functional $A_{2 B}$ receptors are widely distributed 
TABLE 3. Pulmonary inflammation at the end of the 120-minute reperfusion period

\begin{tabular}{|c|c|c|c|}
\hline Group & $\begin{array}{c}\text { TNF- } \alpha \\
(\mathrm{pg} / \mathrm{mL})\end{array}$ & $\begin{array}{l}\text { MPO Activity } \\
\text { ( } \Delta O D / g / m i n)\end{array}$ & Wet/dry weight \\
\hline Control & $1336 \pm 18.9$ & $0.858 \pm 0.012$ & $3.07 \pm 0.08$ \\
\hline $\mathrm{A}_{1}$ agonist & $759 \pm 14.7^{*}, \dagger$ & $0.582 \pm 0.013^{*}, \dagger$ & $2.22 \pm 0.05^{*}$ \\
\hline $\mathrm{A}_{1}$ agonist + antagonist & $1308 \pm 18.7 \dagger$ & $0.810 \pm 0.015 \dagger$ & $2.98 \pm 0.09 \dagger$ \\
\hline $\mathrm{A}_{2 \mathrm{~A}}$ agonist & $804 \pm 17.6^{*}, \dagger$ & $0.482 \pm 0.017^{*}, \dagger, \ddagger$ & $2.08 \pm 0.05^{*}$ \\
\hline $\mathrm{A}_{2 \mathrm{~A}}$ agonist + antagonist & $1326 \pm 18.7 \dagger$ & $0.847 \pm 0.026 \dagger$ & $2.90 \pm 0.18 \dagger$ \\
\hline $\mathrm{A}_{3}$ agonist & $778 \pm 10.5^{*}, \dagger$ & $0.540 \pm 0.016^{*}, \dagger$ & $2.03 \pm 0.08^{*}$ \\
\hline $\mathrm{A}_{3}$ agonist + antagonist & $1287 \pm 13.8 \dagger$ & $0.843 \pm 0.150 \dagger$ & $3.00 \pm 0.06 \dagger$ \\
\hline Adenosine & $978 \pm 26.0^{*}$ & $0.697 \pm 0.028 *$ & $2.41 \pm 0.06^{*}$ \\
\hline
\end{tabular}

$T N F$ - $\alpha$, Tumor necrosis factor; $M P O$, myeloperoxidase. $* P<.0002$ vs control. $\dagger P<.01$ vs adenosine. $\ddagger P<.01$ vs $\mathrm{A}_{1}$ agonist.

on cells, including fibroblasts, various vascular beds, hematopoietic cells, mast cells, and endothelium, ${ }^{28}$ and have recently been shown to be highly expressed on mouse alveolar epithelial cells. ${ }^{29}$ Activation of $\mathrm{A}_{2 \mathrm{~B}}$ receptors has been associated with the release of proinflammatory mediators by activated human mast cells and subsequent release of interleukin- $8{ }^{30}$ In addition, results from Sun and colleagues ${ }^{9}$ suggest that $\mathrm{A}_{2 B}$ receptor signaling influences pathways critical for pulmonary inflammation and injury in vivo. With the recent development of $\mathrm{A}_{2 \mathrm{~B}}$ receptor knockout mice, the role of the $A_{2 B}$ receptor in lung injury will be better understood. In fact, our laboratory has observed that $\mathrm{A}_{2 \mathrm{~B}}$ receptor knockout mice have less lung injury after IR compared with wild-type mice (F. Anvari, MD, unpublished data, May 2010), further supporting a proinflammatory role of the $A_{2 B}$ receptor in lung injury.

\section{Study Limitations}

The current study has several limitations. One limitation of the isolated rabbit lung model is in the length of study. It is difficult to perfuse the lungs beyond 2 hours and maintain stable lungs, and thus we limited the reperfusion time to 2 hours. However, we think the acute period of reperfusion (ie, the first several hours) is a critical time of injury that determines whether a transplant recipient will experience PGD, which is why we focused on this acute time period. It is possible that longer reperfusion times might lead to different results, and we speculate that some of the parameters used to assess lung protection by adenosine receptor agonists, such as oxygenation, would be even more convincing after longer reperfusion.

Another limitation is that we did not use any mechanical maneuvers, such as controlled low-pressure reperfusion, which is often used in the clinical setting. One reason for this is because we wanted to remain consistent with the model used in our previous studies, which produces significant and reproducible injury. It is possible that such mechanical maneuvers would mask the protection offered by adenosine receptor agonists. However, despite such maneuvers used in transplant recipients, there will always be some level of inflammation induced on reperfusion. It is likely that a combination of mechanical maneuvers and adenosine receptor agonists would prove most effective at preventing both immediate endothelial injury and inflammation, as well as later injury and infiltration of inflammatory cells. One of the goals of our study was to directly compare the protective effects of the different adenosine agonists. Some of these differences were small but significant, and these differences may not have been detected if we had used mechanical maneuvers to blunt injury.

\section{CONCLUSIONS}

The results from the present study suggest that selective activation of $A_{1}, A_{2 A}$, or $A_{3}$ adenosine receptors provides protection after lung IR by significantly attenuating both lung dysfunction and injury. As better adenosine receptor agonists are developed and the interactions between adenosine receptors are further elucidated, the pharmacologic modulation of adenosine receptor signaling will likely play an important role in minimizing the vast deleterious effects of IR injury after lung transplantation. Further characterization of protective as well as potentially detrimental effects of adenosine receptor subtypes is required to maximize the possibilities of adenosine-related therapeutics translating to clinical improvements in patient care.

\section{References}

1. Christie JD, Edwards LB, Aurora P, Dobbels F, Kirk R, Rahmel AO, et al. The registry of the international society for heart and lung transplantation: twentysixth official adult lung and heart-lung transplantation Report-2009. J Heart Lung Transplant. 2009;28:1031-49.

2. Ailawadi G, Lau CL, Smith PW, Swenson BR, Hennessy SA, Kuhn CJ, et al. Does reperfusion injury still cause significant mortality after lung transplantation? J Thorac Cardiovasc Surg. 2009;137:688-94.

3. Fiser SM, Tribble CG, Long SM, Kaza AK, Kern JA, Jones DR, et al. Ischemiareperfusion injury after lung transplantation increases risk of late bronchiolitis obliterans syndrome. Ann Thorac Surg. 2002;73:1041-7.

4. Gazoni LM, Laubach VE, Mulloy DP, Bellizzi A, Unger EB, Linden J, et al. Additive protection against lung ischemia-reperfusion injury by adenosine A2A receptor activation before procurement and during reperfusion. J Thorac Cardiovasc Surg. 2008;135:156-65.

5. Reece TB, Ellman PI, Maxey TS, Crosby IK, Warren PS, Chong TW, et al. Adenosine $\mathrm{A} 2 \mathrm{~A}$ receptor activation reduces inflammation and preserves pulmonary function in an in vivo model of lung transplantation. $J$ Thorac Cardiovasc Surg. 2005;129:1137-43. 
6. Sharma AK, Linden J, Kron IL, Laubach VE. Protection from pulmonary ischemia-reperfusion injury by adenosine A2A receptor activation. Respir Res. 2009; 10:58.

7. Rivo J, Zeira E, Galun E, Matot I. Activation of A3 adenosine receptor provides lung protection against ischemia-reperfusion injury associated with reduction in apoptosis. Am J Transplant. 2004;4:1941-8.

8. Todo S, Zhu Y, Zhang S, Jin MB, Ishizaki N, Tanaka H, et al. Attenuation of ischemic liver injury by augmentation of endogenous adenosine. Transplantation. 1997;63:217-23.

9. Sun CX, Zhong H, Mohsenin A, Morschl E, Chunn JL, Molina JG, et al. Role of A2B adenosine receptor signaling in adenosine-dependent pulmonary inflammation and injury. J Clin Invest. 2006;116:2173-82.

10. Jacobson KA. Adenosine A3 receptors: novel ligands and paradoxical effects. Trends Pharmacol Sci. 1998;19:184-91.

11. Day YJ, Li Y, Rieger JM, Ramos SI, Okusa MD, Linden J. A2A adenosine receptors on bone marrow-derived cells protect liver from ischemia-reperfusion injury. J Immunol. 2005;174:5040-6.

12. Cappellacci L, Franchetti P, Vita P, Petrelli R, Lavecchia A, Costa B, et al. 5'-Carbamoyl derivatives of 2'-C-methyl-purine nucleosides as selective A1 adenosine receptor agonists: affinity, efficacy, and selectivity for A1 receptor from different species. Bioorg Med Chem. 2008;16:336-53.

13. Brambilla R, Cattabeni F, Ceruti S, Barbieri D, Franceschi C, Kim YC, et al. Activation of the A3 adenosine receptor affects cell cycle progression and cell growth. Naunyn Schmiedebergs Arch Pharmacol. 2000;361:225-34.

14. Yaar R, Jones MR, Chen JF, Ravid K. Animal models for the study of adenosine receptor function. J Cell Physiol. 2005;202:9-20.

15. Neely CF, Keith IM. A1 adenosine receptor antagonists block ischemiareperfusion injury of the lung. Am J Physiol. 1995;268(6 Pt 1):L1036-46.

16. Rivo J, Zeira E, Galun E, Einav S, Linden J, Matot I. Attenuation of reperfusion lung injury and apoptosis by $\mathrm{A} 2 \mathrm{~A}$ adenosine receptor activation is associated with modulation of bcl-2 and bax expression and activation of extracellular signalregulated kinases. Shock. 2007;27:266-73.

17. Sullivan GW. Adenosine A2A receptor agonists as anti-inflammatory agents. Curr Opin Investig Drugs. 2003;4:1313-9.

18. Linden J. Molecular approach to adenosine receptors: receptor-mediated mechanisms of tissue protection. Annu Rev Pharmacol Toxicol. 2001;41:775-87.
19. Yang Z, Cerniway RJ, Byford AM, Berr SS, French BA, Matherne GP. Cardiac overexpression of A1-adenosine receptor protects intact mice against myocardial infarction. Am J Physiol Heart Circ Physiol. 2002;282:H949-55.

20. Kaminski PM, Proctor KG. Attenuation of no-reflow phenomenon, neutrophil activation, and reperfusion injury in intestinal microcirculation by topical adenosine. Circ Res. 1989;65:426-35.

21. Lee HT, Xu H, Nasr SH, Schnermann J, Emala CW. A1 adenosine receptor knockout mice exhibit increased renal injury following ischemia and reperfusion. Am J Physiol Renal Physiol. 2004;286:F298-306.

22. Zheng J, Wang R, Zambraski E, Wu D, Jacobson KA, Liang BT. Protective roles of adenosine A1, A2A, and A3 receptors in skeletal muscle ischemia and reperfusion injury. Am J Physiol Heart Circ Physiol. 2007;293:H3685-91.

23. Zhong H, Shlykov SG, Molina JG, Sanborn BM, Jacobson MA, Tilley SL, et al. Activation of murine lung mast cells by the adenosine A3 receptor. J Immunol. 2003; $171: 338-45$

24. Polosa R. Adenosine-receptor subtypes: their relevance to adenosine-mediated responses in asthma and chronic obstructive pulmonary disease. Eur Respir J. 2002;20:488-96.

25. van der Hoeven D, Wan TC, Auchampach JA. Activation of the A(3) adenosine receptor suppresses superoxide production and chemotaxis of mouse bone marrow neutrophils. Mol Pharmacol. 2008;74:685-96.

26. Cross HR, Murphy E, Black RG, Auchampach J, Steenbergen C. Overexpression of $\mathrm{A}(3)$ adenosine receptors decreases heart rate, preserves energetics, and protects ischemic hearts. Am J Physiol Heart Circ Physiol. 2002;283:H1562-8.

27. Tracey WR, Magee WP, Oleynek JJ, Hill RJ, Smith AH, Flynn DM, et al. Novel N6-substituted adenosine 5'-N-methyluronamides with high selectivity for human adenosine A3 receptors reduce ischemic myocardial injury. Am J Physiol Heart Circ Physiol. 2003;285:H2780-7.

28. Feoktistov I, Biaggioni I. Adenosine A2B receptors. Pharmacol Rev. 1997;49: 381-402.

29. Cagnina RE, Ramos SI, Marshall MA, Wang G, Frazier CR, Linden J. Adenosine A2B receptors are highly expressed on murine type II alveolar epithelial cells. Am J Physiol Lung Cell Mol Physiol. 2009;297:L467-74.

30. Feoktistov I, Biaggioni I. Adenosine A2b receptors evoke interleukin-8 secretion in human mast cells. An enprofylline-sensitive mechanism with implications for asthma. J Clin Invest. 1995;96:1979-86. 